\title{
Eksistensi Pendidikan Karakter Peserta Didik dalam Balutan Full Day School
}

\author{
Oleh : \\ Alfiyatul Imaniyah \\ SMK Teuku Umar Semarang \\ (alfiyaunwahas24@gmail.com)
}

\begin{abstract}
Abstrak
Tulisan ini akan membahas tentang eksistensi pendidikan karakter di sekolah dalam konsep full day school. Sekolah merupakan lembaga yang berperan sebagai penyelenggara pendidikan dan pengembangan ilmu, pengetahuan, teknologi dan seni. Tujuan pendidikan ialah membentuk kepribadian, kemandirian, keterampilan social dan karakter. Oleh sebab itu, berbagai program dirancang dan diimplementasikan untuk mewujudkan tujuan pendidikan tersebut, terutama dalam rangka pembinaan karakter. Full day school akhir-akhir ini yang menjadi kontro versi dikalangan masyarakat pun menempati tempat ternyaman. Dibuktikan dengan menjamurnya sekolah-sekolah yang mulai menerapkan full day school untuk meningkatkan kualitas pendidikan karakter siswa khususnya.
\end{abstract}

Kata kunci : Pendidikan Karakter, Peserta Didik, Full day School

\section{Abstract}

This writing is presenting about the existence of character education in schools in the concept of full day school. School is an institution that acts as a provider of education and development of science, knowledge, technology and art. The purpose of education is to shape the personality, independence, social skills and character. Therefore, various programs are designed and implemented to realize the purpose of education, especially in the context of character building. Full day school lately which became the contro version of society also occupies the most comfortable place. It is proven by the proliferation of schools that start implementing full day school to improve the quality of character education of students in particular.

Keywords: Character Education, Educate Participants, Full day School 


\section{A. Pendahuluan}

Pendidikan ialah proses internalisasi kultur kedalam individu dan masyarakat sehingga menjadi beradab. Pendidikan bukan sarana transfer ilmu pengetahuan saja, namun sebagai sarana proses pengkulturan dan penyaluran nilai (enkulturisasi dan sosialisasi). Tujuan pendidikan adalah humaniora dan bukan pengetahuan praktis sebagai bekal untuk mencari pekerjaan, yang mengarah pada pencarian status sosial.

Sekolah merupakan lembaga yang berperan sebagai penyelenggara pendidikan dan pengembangan ilmu, pengetahuan, teknologi dan seni. Tujuan pendidikan ialah membentuk kepribadian, kemandirian, keterampilan social dan karakter. Oleh sebab itu, berbagai program dirancang dan diimplementasikan untuk mewujudkan tujuan pendidikan tersebut, terutama dalam rangka pembinaan karakter.

Karakter secara etimologis berasal dari bahasa Latin, kharakter, kharassein dan kharax yang berarti tool for making to engrave and pointed stake. Pada abad ke-14 kata ini sering digunakan dalam bahasa Perancis dan kemudian di adopsi bahasa Inggris sehingga menjadi karaktere yang bermakna watak, karakter atau sifat.1 Konsep karakter pertama kali digagas oleh paedagog Jerman F.W.Forster, menurut bahasa, karakter berarti kebiasaan. Sedangkan menurut istilah, karakter ialah sebuah sistem keyakinan dan kebiasaan yang mengarahkan

1Wakhrodi, Pendidikan Karakter di Pesantren Dalam Pemikiran K.H MA. Sahal Mahfudh, JURNAL ISLAMIC REVIEW “J.I.F”( Jurnal Riset Dan Kajian Keislaman), STAIMAFA Press, Volume II (1 April 2013), H. 91. 
tindakan seorang individu. Studi karakter telah lama menjadi pokok perhatian psikolog, paedagog dan pendidik. Sudut pandang mereka tentu berbeda-beda sesuai penekanan dan pendekatan masing-masing. Sedangkan secara etimologi, kata karakter berasal dari bahasa Inggris (Character) dan Yunani (Character) yang berarti membuat tajam, membuat dalam. Menurut Kamus Besar Bahasa Indonesia, karakter diartikan sebagai sifat-sifat kejiwaan, etika atau budi pekerti yang membedakan individu dengan yang lain.2

Menurut Koentjaraningrat dan Mochtar Lubis, rerata karakter bangsa Indonesia terpusat pada meremehkan mutu, suka menerabas, tidak percaya diri sendiri, tidak disiplin, mengabaikan tanggung jawab, hipokrit, lemah kreativitas, etos kerja buruk, suka feodalisme, dan tidak punya malu. Karakter lemah tersebut menjadi realitas dalam kehidupan bangsa Indonesia. Nilai-nilai tersebut sudah ada sejak bangsa Indonesia masih dijajah bangsa asing beratus-ratus tahun yang lalu. Karakter tersebut akhirnya mengkristalisasi pada masyarakat Indonesia. Bahkan ketika bangsa ini sudah merdeka pun karakter tersebut masih melekat. Kondisi inilah yang kemudian melatarbelakangi lahirnya pendidikan karakter oleh Kementrian Pendidikan dan Kebudayaan.3

Di zaman modern ini pendidikan menjadi tantangan dan sebagai upaya alternatif jalan keluarnya yaitu dengan

2Departemen Pendidikan Nasional, Kamus Besar Bahasa Indonesia,Jakarta:

PT. Gramedia Pustaka Utama, Edisi IV cet. 1. 2008,h.623.

3 Retno Listyarti, Pendidikan Karakter dalam metode Aktif, Inovatif \& Kreatif, Jakarta: esensi, 2012, h. 4-6. 
mengembangkan pola pendidikan yang lebih kreatif. Sebagai upaya menanggapi dan menghadapi pesatnya perkembangan zaman diperlukan sebuah program pendidikan yang direncanakan secara sistematis, melalui sebuah kurikulum yang mempunyai peranan sangat penting bagi pendidikan siswa. Kurikulum berperan dalam melakukan berbagai kegiatan kreatif dan konstruktif, dalam artian menciptakan dan menyusun suatu hal yang baru sesuai dengaan kebutuhan masyarakat di masa sekarang dan masa mendatang. Sistem baru full day school sebagai bentuk alternatif dalam upaya memperbaiki manajemen pendidikan, khususnya dalam manajemen pembelajaran dan juga merupakan tuntutan kebutuhan masyarakat yang menghendaki anak dapat belajar dengan baik di sekolah dengan waktu belajar lebih lama. Full day school merupakan model pembelajaran dengan menambah waktu belajar siswa dari pagi hingga sore hari. Dengan begitu kecenderungan bagi siswa untuk bersifat asosial bisa teratasi.4

Sebagaimana pada setelah dilantiknya Menteri Pendidikan dan Kebudayaan RI, Muhadjir Effendy mengenai wacana sekolah sehari penuh (full day school). Full Day School ini tidak berarti peserta didik belajar seharian penuh di sekolah, tetapi memastikan bahwa peserta didik dapat mengikuti kegiatan-kegiatan penanaman pendidikan karakter, seperti mengikuti kegiatan ekstrakurikuler. Diharapkan peserta didik

4Nurul Farid, Hubungan Antara Pelaksanaan Pendidikan Full Day School dengan Perilaku Sosial Keagamaan Di Luar Sekolah (Siswa SMP Muhammadiyah 12 Gresik), Tesis, (Surabaya: IAIN Sunan Ampel, 2009), hal. 3, dalam google.com, diakses pada 20 September 2017, pukul 19.00 wib. 
dapat terhindar dari pengaruh-pengaruh negatif dan kontra produktif, seperti penyalahgunaan narkoba, tawuran, dan sebagainya.

Sementara sebagian masyarakat menilai, Full day school merupakan sebuah program prematur yang disusun berdasarkan ketidakyakinan pemerintah terhadap peran orangtua dan masyarakat dalam pendidikan karakter anak. Bahkan puluhan ribu warga masyarakat menandatangani petisi untuk menolak pelaksanaan Full Day School. Padahal jika dikaji lebih dalam, bahwa Full Day School merupakan program yang sebetulnya mampu membentuk karakter peserta didik. Diketahui banyak terjadi perilaku menyimpang yang dilakukan peserta didik. Seperti tawuran dan kekerasan yang dilakukan peserta didik yang mestinya tidak perlu terjadi. Kemudian salah satu perilaku menyimpang yang marak sekarang ini adalah bully antar peserta didik. Bahkan anak-anak yang pernah di bully ini cenderung lebih memiliki masalah mental pada masa dewasanya dibandingkan dengan orang-orang yang pernah dianiaya oleh orang dewasa. Dengan demikian, maksud dari adanya konsep full Day School masalah mengenai kegiatan penyimpanganpenyimpangan sosial di kalangan remaja dapat diminimalisir. 


\section{B. Pembahasan}

\section{Eksistensi dan Konsep Pendidikan Karakter Peserta} Didik

Menurut Kemdiknas, tujuan pendidikan karakter pada dasarnya adalah mendorong lahirnya anak-anak yang baik (insan kamil). Tumbuh dan berkembangnya karakter yang baik, akan mendorong peserta didik tumbuh dengan kapasitas dan komitmennya, untuk melakukan berbagai hal yang terbaik, dan melakukan segalanya dengan benar serta memiliki tujuan hidup. Masyarakat juga berperan dalam membentuk karakter anak melalui orang tua dan lingkungannya. Selanjutnya, pendidikan karakter dikembangkan melalui tahap pengetahuan (knowing), pelaksanaan (acting), dan kebiasaan (habit). Pendidikan karakter tidak terbatas pada pengetahuan saja. seseorang yang memiliki pengetahuan kebaikan belum tentu mampu bertindak sesuai dengan pengetahuannya, jika tidak terlatih (menjadi kebiasaan) untuk melakukan kebaikan tersebut.

Pendidikan karakter hendaknya juga menjangkau wilayah emosi dan kebiasaan diri. Dengan demikian diperlukan tiga komponen karakter yang baik (component of good character) yaitu moral knowing (pengetahuan tentang moral), moral feeling atau perasaan (penguatan emosi) tentang moral, dan moral action atau perbuatan moral. Hal ini diperukan agar peserta didik dan atau warga sekolah lain yang terlibat dalam system pendidikan tersebut sekaligus 
dapat memahami, merasakan, menghayati, dan mengamalkan (mengerjakan) nilai-nilai kebajikan (moral). Sehingga dalam mengimplementasikan pendidikan karakter, komunitas sekolah tidak bekerja dan berjuang sendiri. Akan tetapi, sekolah hendaknya bekerjasama dengan masyarakat di luar lembaga pendidikan, seperti keluarga, masyarakat umum, dan Negara.5

Berbicara mengenai pendidikan karakter, hal yang utama dikaji adalah sasaran kita dalam menerapkan pendidikan karakter itu sendiri yang tak lain adalah peserta didik sebagai objek atau sasaran penerima ransangan yang diberikan oleh subjek. Menurut pasal 1 ayat 4 UU RI No. 20 Tahun 2003 tentang Sistem Pendidikan Nasional, peserta didik adalah anggota masyarakat yang berusaha mengembangkan dirinya melalui proses pendidikan pada jalur jenjang dan pendidikan tertentu.6 Dalam perspektif psikologis, peserta didik adalah individu yang sedang berada dalam proses pertumbuhan dan perkembangan, baik fisik maupun psikis menurut fitrahnya masing-masing. Sedangkan dalam perspektif pedagogis, peserta didik diartikan sebagai sejenis makhluk homo educandum, makhluk yang menghajatkan pendidikan. Dalam pengertian ini, peserta didik dipandang sebagai manusia yang memiliki potensi yang bersifat laten, sehingga dibutuhkan binaan dan 
bimbingan untuk mengaktualisasikannya agar ia dapat menjadi manusia susila yang cakap.7

Karena peserta didik merupakan komponen manusiawi yang terpenting dalam proses pendidikan, maka seorang guru dituntut memiliki pemahaman yang mendalam tentang hakikat peserta didik tersebut. Sebagai komponen manusiawi, berarti pemahaman tentang hakikat peserta didik terlepas dari pemahaman tentang hakikat manusia secara umum. Dalam kajian psikologi terdapat sejumlah teori berupaya untuk menjelaskan tentang hakikat manusia, terutama tentang bagaimana manusia berkembang dan bertingkah laku, faktor-faktor apa saja yang mempengaruhi manusia sehingga mampu mendinamisasikan dirinya dalam berbagai perilaku kehidupan.

a. Pengertian Peserta Didik

Peserta didik secara umum maupun menurut Pendidikan Islam sama, yaitu individu yang sedang tumbuh dan berkembang fisik, psikologi, sosial dan religius dalam mengarungi kehidupan dunia akhirat.

b. Karakter Peserta Didik

1) Peserta didik bukan miniatur orang dewasa, artinya mereka punya "dunianya sendiri"

2) Peserta didik memiliki kebutuhan (basic need). (basic : makan, minum, rasa aman, dan lain-lain. Need : terkait aktualisasi diri :keadilan, baik, teratur) 
3) Peserta didik memiliki perbedaan-perbedaan, dari sisi endogen dan eksogennya.

4) Peserta didik : monopluralis (punya rasa, karsa dan cipta)

5) Peserta didik :obyek dan subyek pendidikan sekaligus.

c. Periode perkembangan peserta didik

1) Fase Neonatus (tahap asupan : 0-2 tahun)

a) Diadzani dan diiqomati pada telinga kanan-kiri

b) Memotong hewan aqiqah

c) Memberi nama yang baik

d) Membiasakan hidup bersih

e) Memberi ASI sampai 2 tahun

f) Memberimakan atau minum yang halal

2) Fase Kanak (2-11 tahun), terjadi perkembangan potensi, biologis, psikologis dan paedagogis.

3) Fase Tamyiz (12-20 tahun), baligh atau remaja (mampu membedakan baik atau buruk, benar atau salah). Fase Mu'allaf, kecerdasan akalnya berkembang dan kecakapannya berbuat sesuatu. Di sini komitmen "uswatun hasanah" dari orang tua atau guru.

4) Tahap Kematangan (20-30 tahun), kedewasaan yang sebenarnya (biologis, psikologis, sosiologis, religious), mencapai kematangan dalam mengambil sikap dan tindakan untuk mentukan masa depannya. 
5) Tahap Kebijaksanaan (30-40 Tahun), fase usia lanjut atau sudah menemukan jatidirinya.

6) Lebih dari 40 tahun (live begin fourty), mampu memberikan perlindungan atau nasehat pada orang lain.8

Konsep pendidikan karakter pada siswa bukanlah berupa materi yang hanya bisa dicatat dan dihafalkan serta tidak dapat dievaluasi dalam jangka waktu yang pendek, tetapi pendidikan karakter merupakan sebuah pembelajaran yang teraplikasi dalam semua kegiatan siswa, baik di sekolah, lingkungan masyarakat, dan di lingkungan rumah melalui proses pembiasaan, keteladanan, dan dilakukan secara berkesinambungan.

Eksistensi dari keberhasilan karakter ini tidak bisa dinilai dengan penilaian formatif atau sumatif yang dinyatakan dalam skor. Tetapi tolak ukur dari keberhasilan pendidikan karakter adalah terbentukya peserta didik yang berkarakter, berakhlak, berbudaya, santun, religius, kreatif, inovatif, yang teraplikasi dikehidupan di sepanjang hayatnya. Oleh sebab itu, tentu tidak ada alat ukur yang tepat dan serta merta dapat menunjukkan keberhasilan pendidikan karakter. 


\section{Pendidikan Karakter Peserta Didik Melalui FDS Secara} Terprogram

Untuk merealisasikan pendidikan karakter dalam kehidupan setiap orang, maka pembudayaan kebiasaankebiasaan baik menjadi suatu hal yang niscaya. Di sekolah atau lembaga pendidikan, upaya ini dilakukan melalui pemberian mata pelajaran pendidikan akhlak, pendidikan moral, pendidikan etika, atau pendidikan karakter. Akhirakhir ini di Indonesia misi ini diemban oleh dua mata pelajaran pokok, yakni Pendidikan Agama dan Pendidikan Kewarganegaraan. Kedua mata pelajaran ini tampaknya belum dianggap mampu mengantarkan peserta didik memiliki kebiasaan-kebiasaan baik seperti yang diharapkan, sehingga sejak 2003 melalui Undang-undang Sistem Pendidikan Nasional 2003 dan dipertegas dengan dikeluarkannya PP 19 tahun 2005 tentang Standar Nasional Pendidikan, pemerintah menetapkan, setiap kelompok mata pelajaran dilaksanakan secara holistik sehingga pembelajaran masing-masing kelompok mata pelajaran memengaruhi pemahaman dan/atau penghayatan peserta didik (PP 192005 pasal 6 ayat 4). Pada pasal 7 ayat (1) ditegaskan bahwa Kelompok mata pelajaran agama dan akhlak mulia pada SD/MI/SDLB/Paket A, SMP/MTs/SMPLB/ Paket B, SMA/MA/ SMALB/ Paket C, SMK/MAK, atau bentuk lain yang sederajat dilaksanakan melalui muatan dan/atau kegiatan agama, kewarganegaraan, kepribadian, ilmu 
pengetahuan dan teknologi, estetika, jasmani, olah raga, dan kesehatan.

Untuk menciptakan anak yang mempunyai kebiasaan-kebiasaan baik, pengajar tidak cukup hanya memberikan prinsip saja, karena yang lebih penting bagi siswa adalah figur yang memberikan keteladanan dalam menerapkan prinsip tersebut. Sehingga sebanyak apapun prinsip yang diberikan tanpa disertai dengan contoh teladan hanya akan menjadi kumpulan resep tak bermakna. Seperti yang diungkapkan oleh Bunyamin, Kepala Dinas Pendidikan Kota Semarang, bahwasannya sikap ramah guru terhadap siswa harus terus ditingkatkan selama proses belajarmengajar berlangsung. Tidak ada pihak yang berlaku kasar dalam memberikan pendidikan di lingkungan sekolah. Rasa cinta dan kasih sayang harus didahulukan oleh guru dan orang tua. Hal ini diharapkan tugas guru sebagai pendidik pertama di lingkungan sekolah, dan ke-2 satelah orang tua sebagai agen pendidikan siswa di rumah tidak hanya memberi ilmu pengetahuan saja, akan tetapi juga memberikan kebiasaan-kebiasaan yang mupuk karakter perilaku yang baik bagi peserta didiknya."prinsip ini tentunya harus bisa dipegang teguh. Pembelajaran bisa dilakukan dengan cara-cara yang baik dan tidak perlu 
bersikap kasar," tutur Kepala Dinas Pendidikan Kota Semarang, Bunyamin.9

Kebiasaan-kebiasaan baik dengan memulai dari halhal kecil yang bermanfaat di lingkungan sekolah atau pendidikan misalnya, harus tercermin dalam praktik kehidupan sehari-hari semua warga sekolah yang meliputi karyawan, guru, para siswa, dan kepala sekolah. Semua komponen sekolah, harus menghiasi dirinya dengan akhlak yang mulia, seperti berlaku jujur, amanah, tanggungjwab, rasa hormat, peduli, santun, lapang dada, toleran, tekun dan sabar. Dengan menanamkan dan mempraktikkan sikap dan perilaku tersebut, maka pada waktunya kelak akan terbangun kultur kebiasaan-kebiasaan berkarakter yang terbiasa dilakukan di lingkungan sekolah.10

Melakukan pendidikan adalah usaha bersama antara keluarga, sekolah dan masyarakat. Antara ketiga lembaga tersebut senantiasa berjalan secara terpadu, untuk memajukan satu tujuan yang bersifat saling melengkapi antara satu dengan yang lainnya. Berdasar realitas dan peranan ketiga lembaga tersebut, maka ahli pendidikan Khi Hajar Dewantara menganggap ketiganya adalah tri pusat pendidikan artinya tiga pusat pendidikan yang secara

9Bunyamin, Kepala Dinas Pendidikan Kota Semarang, Sikap Ramah Guru Diminta Ditingkatkan, Suara Merdeka, Bag. Semarang Metro, 2 Oktober 2015, kol. 28.

10Ajat Sudrajat, Membangun Kultur Akhlak Mulia Di Kalangan Siswa Sekolah Dasar Dan Menengah Di Indonesia, Jurnal Ilmu Sejarah, Jurnal Ilmiah FISE UNY, t.th., dalam google.com, diakses tanggal : 20 September 2017 jam 06.00. 
bertahap dan terpadu mengembangkan tanggung jawab pendidikan bagi generasi mudanya. Kemudian asas tersebut dijadikan kebijakan Negara kita yang tertanam dalam GBHN tahun 1978 yang menetapkan prinsip sebagai berikut: "Pendidikan berlangsung seumur hidup dan dilaksanakan di dalam lingkungan rumah tangga, sekolah dan masyarakat, karena itu pendidikan adalah tanggung jawab bersama antara keluarga, masyarakat, dan pendidikan". Oleh karena itu sebagai upaya antisipasi dan memberikan alternatif sekolah yang berorientasi masa depan, serta untuk menyiapkan generasi yang dapat mengantisipasi dan berkompetisi di era global. Maka perlu diadakan perubahan didalam system maupun kurikulumnya.

Pendidikan, sekali lagi dalam momentum historisnya ternyata tetap merupakan ajang pemikiran yang tak pernah usai. Kerangka idealis pendidikan, yang secara istilah bertujuan untuk menciptakan manusia Indonesia terdidik, dalam kenyataannya selalu dibarengi oleh munculnya prilaku tak terdidik. Meningkatnya yel-yel moralitas yang ditopang dengan strukturisasi kurikulum yang kian dinamis (modern) berbanding pararel dengan mencuatnya realitasrealitas yang cenderung amoral. Upaya-upaya konsepsional dimana pemerintah sebagai pelopornya, menunjukkan bahwa pendidikan merupakan unsur utama dan pertama bagi terciptanya atmosfer masyarakat bangsa yang hakiki, yang tetap berpegang teguh pada unsur-unsur etika moral 
nenek moyang sendiri dan secara global bersumber dari norma-norma agama.

Dengan adanya perubahan paradigma pendidikan diatas, maka banyak bermunculan metode-metode pendidikan versi baru yang notabene moral. Salah satu diantaranya adalah sekolah sehari penuh atau Full Day School. Sistem Full Day School (FDS) ini diformat untuk mengembangkan dan meningkatkan tingkat kecerdasan Intellegence Quotient (IQ), Emitional Quotient (EQ), Spiritual Quotient (SQ), dan Skill Quotient (SQ). Dengan berbagai inovasi pendidikan yang efektif dan actual. Sebagai sistem yang masih tergolong baru dikalangan pendidikan pada umumnya dan sudah lama diterapkan di sekolah-sekolah yang berbau pesantren, full day school merupakan suatu sistem yang masih asing bagi kebanyakan sekolah yang ada di indonesia, sehingga masih sangat jarang sekolah yang menerapkan sistem ini dalam meningkatkan prestasi belajar siswa. Akan tetapi pendidikan model demikian itu, kini mulai semakin mencuat ditengah-tengah suasana magnetis dua kutub yang berbeda, kualitas dan kuantitas. Kenyataan sosial semisal bertumbuh kembangnya "orang tua-orang tua baru (pembantu) yang mengganti status orang tua yang sebenarnya". Sebagai dampak globalisasi ekonomi materialistik, yang konon merupakan awal dari segala bentuk perilaku naif dan amoral anak-anak bangsa, merupakan stimulus terkuat yang melatar belakangi 
bergulirnya konsep Full Day School, dengan menyediakan waktu sehari penuh untuk pendidikan putra-putri bangsa terutama bagi anak-anak terlantar akibat globalisasi ekonomi tersebut, disamping motif-motif lainnya.

\section{Penutup}

Sekolah, merupakan lingkungan artifisial yang sengaja dibentuk guna mendidik dan membina generasi muda ke arah tujuan tertentu, terutama untuk membekali anak dengan pengetahuan dan kecakapan hidup yang dibutuhkan dikemudian hari. Dalam proses pendidikan, peserta didik merupakan salah satu komponen manusiawi yang menempati posisi sentral. Peserta didik atau siswa menjadi pokok persoalan dan tumpuan perhatian dalam semua proses transformasi yang disebut pendidikan. Sebagai salah satu komponen penting dalam sistem pendidikan, siswa atau peserta didik sering disebut sebagai raw material (bahan mentah). Karena peserta didik merupakan komponen manusiawi yang terpenting dalam proses pendidikan, maka seorang guru dituntut memiliki pemahaman yang mendalam tentang hakikat peserta didik tersebut. Melalui Sistem Full Day School (FDS) ini diharapkan seorang pendidik dapat mengembangkan dan meningkatkan tingkat kecerdasan Intellegence Quotient (IQ), Emitional Quotient (EQ), Spiritual Quotient (SQ), dan Skill Quotient (SQ) pada peserta didik.

Uraian diatas memperkuat pentingnya sebuah pendidikan karakter pada peserta didik dimanapun, kapanpun dan dalam 
posisi apapun. Dengan kata lain, eksistensi pendidikan karakter akan terus menjadi pusat perhatian di dunia pendidikan. (1) Kontra versi mengenai sistem Full Day School (FDS) memang tidak bisa terelakkan. (2) Dalam pelaksaannya, perlu di adakannya evaluasi secara bertahap mengenai program Full Day School dimulai oleh pendidik selaku agen pendidikan dari hal kecil dengan melakukan kebiasaan-kebiasaan baik yang dapat membentuk karakter peserta didik. (3) perlu diadakannya pembaharuan atau inovasi-inovasi dalam program Full Day School, karena sebuah sistem bisa berubah mengikuti kebutuhan dan perkembangan zaman. (4) Upaya menghasilkan generasi yang mempunyai kebiasaan-kebiasaan baik, pengajar tidak cukup hanya memberikan prinsip saja, karena yang lebih penting bagi siswa adalah figur yang memberikan contoh membiasakan kebiasaan baik dalam menerapkan prinsip tersebut. 


\section{DAFTAR PUSTAKA}

Bunyamin, Kepala Dinas Pendidikan Kota Semarang, Sikap Ramah Guru Diminta Ditingkatkan, Suara Merdeka, Bag. Semarang Metro, 2 Oktober 2015.

Desmita, Psikologi Perkembangan Peserta Didik, cet. ke-5, Bandung : PT Remaja Rosdakarya, 2014.

Farid, Nurul., Hubungan Antara Pelaksanaan Pendidikan Full Day School dengan Perilaku Sosial Keagamaan Di Luar Sekolah (Siswa SMP Muhammadiyah 12 Gresik), Tesis, (Surabaya: IAIN Sunan Ampel, 2009), dalam google.com, diakses pada 20 September 2017, pukul 19.00 wib.

Listyarti, Retno., Pendidikan Karakter dalam metode Aktif, Inovatif \& Kreatif, Jakarta: esensi, 2012.

Pendidikan Nasional, Departemen., Kamus Besar Bahasa Indonesia,Jakarta : PT. Gramedia Pustaka Utama, Edisi IV cet. 1. 2008.

Sisdiknas, Undang-Undang., t.t, t.p, 2003.

Sudrajat, Ajat., Membangun Kultur Akhlak Mulia Di Kalangan Siswa Sekolah Dasar Dan Menengah Di Indonesia, Jurnal Ilmu Sejarah, Jurnal Ilmiah FISE UNY, t.th., dalam google.com, diakses tanggal : 20 September 2017 jam 06.00.

Thohir, Asro'ie., Ilmu Pendidikan Islam, t.th., Semarang: UNWAHAS

Wakhrodi, Pendidikan Karakter di Pesantren Dalam Pemikiran K.H MA. Sahal Mahfudh, JURNAL ISLAMIC REVIEW “J.I.F”( Jurnal Riset Dan Kajian Keislaman), STAIMAFA Press, Volume II (1 April 2013).

Wibowo, Agus., "Manajemen Pendidikan Karakter di Sekolah", Yogyakarta: Pustaka Pelajar, 2013. 